\section{Deaths and paradoxes after intentional insulin overdosage}

Deliberate self poisoning with insulin is uncommon and documented mainly as case reports. ${ }^{1-3}$ During $1978-81$ we managed 20 episodes of insulin self poisoning; two of the patients died.

\section{Patients, methods, and results}

Of 15 patients (eight men, seven women, aged 16-43), 12 were insulin dependent diabetics and three non-diabetics (two were wives of diabetics and one a nurse). Twelve episodes of self poisoning were due to injection of one insulin alone and the remaining eight to injection of mixtures of insulins with different durations of action.

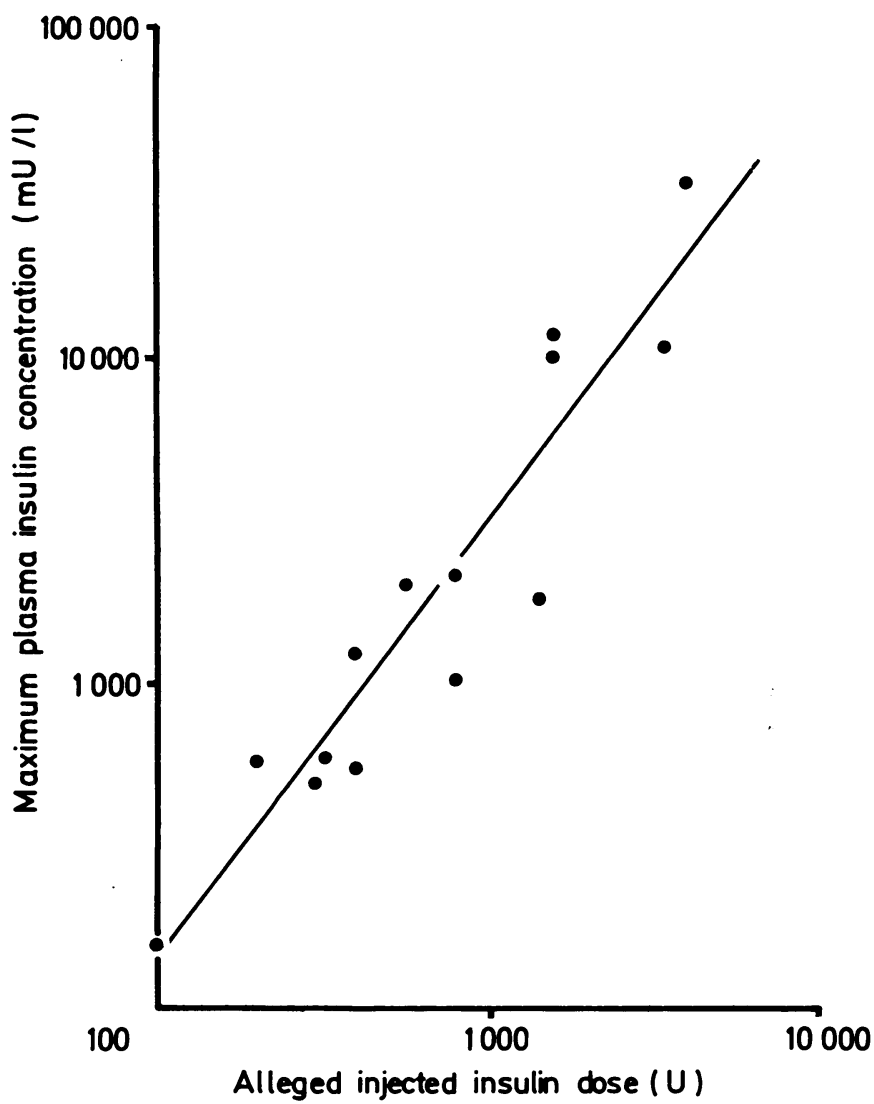

Correlation on logarithmic scales between alleged doses of insulin injected and maximum plasma immunoreactive insulin concentrations in 14 patients.

In 18 episodes admission to hospital was within nine hours of injection, and coma occurred in only six. The patients recovered uneventfully after being given $50 \mathrm{ml} 50 \%$ dextrose followed by an infusion of $5 \%$ or $10 \%$ dextrose at a rate of one litre every four hours and then one litre every eight hours for 24-36 hours. Five patients had symptoms suggesting hypoglycaemia but a normal plasma glucose concentration on one to three occasions two to eight hours after dextrose infusions were started. All suspected hypoglycaemic episodes were treated with $25 \mathrm{~g}$ or $50 \mathrm{~g}$ glucose orally or intravenously. Within 24 hours of admission each patient was able to eat solid food and had norma temperature, pulse, and blood pressure. When sufficiently cooperative they were interviewed by psychiatrists before discharge.

Two men were admitted to hospital deeply unconscious more than 12 hours after injection. They had ingested large amounts of alcohol after several days of reduced food intake and failed to respond despite intravenous glucagon, dexamethasone, $20 \%$ mannitol, dextrose infusions, and intensive sup portive care. Necropsy showed hypoglycaemic brain damage with cortical laminar necrosis and, in one case, cerebral and mid-brain infarcts.

The figure shows that maximum plasma immunoreactive insulin concentrations (154-32 $000 \mathrm{mU} / \mathrm{l})$ correlated well $(r=0.94)$ with the alleged dose of insulin injected. Plasma glucose concentrations before treatment were 0.5-5.4 (mean 1.6) mmol/1 (9-97 (mean 29) $\mathrm{mg} / 100 \mathrm{ml}$ ) and did not correlate with corresponding plasma insulin concentrations; during treatment they fluctuated considerably in individual patients, although normoglycaemia was usually maintained and many patients were hyperglycaemic. Three patients with hypokalaemia and six with normokalaemia were given potassium supple- ments; none of the remainder developed hypokalaemia. There was no correlation between plasma concentrations of potassium and glucose on admission. Plasma concentrations of urea, sodium, and bicarbonate remained normal.

\section{Comment}

All but two patients responded promptly to bolus injections of dextrose, and continuous infusion of dextrose over 24-36 hours prevented appreciable hypoglycaemia. An artificial pancreas may be the most accurate way to maintain normoglycaemia but is clearly not essential. ${ }^{4}$ There is an obvious disparity between plasma insulin concentrations after overdose and the biological effects as even in insulin dependent diabetics normal concentrations rarely rise above $100-200 \mathrm{mU} / 1$. Possible explanations for this paradox include the release of catabolic counter-regulatory hormones, insulin receptor down regulation, or postreceptor defects preventing severe hypoglycaemia.

Overnight delay in reaching hospital and considerable consumption of alcohol after several days of reduced food intake were probably the main reasons that two patients died while others with higher plasma insulin concentrations did not even lose consciousness, as alcohol inhibits gluconeogenesis and the hyperglycaemic action of counterregulatory hormones. ${ }^{5}$

Massive insulin overdosage can be managed with ease if promptly treated, but if it is combined with consumption of alcohol and treatment is delayed an overdose can result in fatal brain damage.

' Beardwood JT. A case of attempted suicide with insulin. $\mathcal{F} A M A$ 1934;102:

$765-6$.
Munck O, Quaade F. Suicide attempted with insulin. Dan Med Bull 1963;10: 139-4

Martin FIR, Hansen N, Warne GL. Attempted suicide by insulin overdose in insulin-requiring diabetics. Med $\mathcal{F}$ A A st 1977;1:58-60.

- Gin H, Larnaudie B, Aubertin J. Attempted suicide by insulin injection treated with artificial pancreas. Br Med f 1983;287:249-50.

Marks V, Rose FC. Alcohol-induced hyperglycaemia. In: Hypoglycaemia. 2nd ed. Oxford: Blackwell Scientific Publications, 1981:387-98.

(Accepted 4 May 1984)

Regional Poisoning Treatment Centre, Royal Infirmary, Edinburgh EH3 9YW

J A J H CRITCHLEY, PHD, MRCP, lecturer and senior registrar in therapeutics and clinical pharmacology

A T PROUDFOOT, BSC, FRCPED, consultant physician

Victoria Hospital, Kirkcaldy, Fife KY2 5AH

S G BOYD, MB, CHB, medical registrar

I W CAMPBELL, MB, FRCPED, consultant physician

Immunoassay Section, Department of Clinical Chemistry, Royal Infirmary, Edinburgh EH3 9YW

N S BROWN, MA, MRCPATH, senior biochemist

Department of Neuropathology, Western General Hospital, Edinburgh EH4 2XU

A GORDON, MD, consultant neuropathologist

Correspondence to: Dr J A J H Critchley.

\section{A hepatitis like picture in typhoid fever}

Typhoid fever has myriad complications. A hepatitis like picture, however, is distinctly uncommon. I present five cases of "hepatitis typhosa" seen over two years.

\section{Patients, methods, and results}

From December 1980 to December 1982 five cases of jaundice associated with typhoid fever were detected in this hospital. The five patients were male with a mean age of 17.6 years. They were admitted with a fever of four to 20 days' duration. All appeared very ill and had associated headache, vomiting, and abdominal discomfort. Three of the patients had jaundice on admission, although it was uncertain when this had first developed; the diagnosis on admission was viral hepatitis. In the two others the jaundice had developed on the 11 th and 23 rd day of the fever. All patients had tender hepatomegaly and four had a palpable spleen. None had received specific chemotherapy before admission. 
Results of liver function tests, showing peak biochemical values. (Normal ranges are shown in parentheses)

\begin{tabular}{|c|c|c|c|c|c|c|c|}
\hline Case No & $\begin{array}{c}\text { Age } \\
\text { (years) }\end{array}$ & $\begin{array}{c}\text { Duration of } \\
\text { fever on } \\
\text { admission } \\
\text { (days) }\end{array}$ & $\begin{array}{l}\text { Time when } \\
\text { jaundice noted }\end{array}$ & $\begin{array}{c}\text { Serum } \\
\text { bilirubin } \\
(\mu \mathrm{mol} / 1) \\
(5-17 \mu \mathrm{mol} / 1)\end{array}$ & $\begin{array}{c}\text { Alkaline } \\
\text { phosphatase } \\
(3-13 \mathrm{KAU})\end{array}$ & $\begin{array}{c}\text { Serum } \\
\text { alanine } \\
\text { transferase } \\
(3-30 \text { U/1) }\end{array}$ & $\begin{array}{c}\text { Total } \\
\text { duration } \\
\text { of fever } \\
\text { (days) }\end{array}$ \\
\hline $\begin{array}{l}1 \\
2 \\
3 \\
4 \\
5\end{array}$ & $\begin{array}{l}19 \\
17 \\
12 \\
15 \\
26\end{array}$ & $\begin{array}{r}20 \\
4 \\
7 \\
15 \\
12\end{array}$ & $\begin{array}{l}\text { 23rd day of fever } \\
\text { On admission } \\
11 \text { th day of fever } \\
\text { On admission } \\
\text { On admission }\end{array}$ & $\begin{array}{r}133 \\
125 \\
65 \\
58 \\
75\end{array}$ & $\begin{array}{l}20 \cdot 0 \\
17 \cdot 5 \\
18 \cdot 0 \\
34 \cdot 0 \\
80 \cdot 0\end{array}$ & $\begin{array}{r}675 \\
237 \\
195 \\
255 \\
45\end{array}$ & $\begin{array}{l}51 \\
18 \\
18 \\
24 \\
23\end{array}$ \\
\hline
\end{tabular}

Conversion: SI to traditional units-Bilirubin: $1 \mu \mathrm{mol} / 1 \approx 58.5 \mu \mathrm{g} / 100 \mathrm{ml}$.

Blood culture grew Salmonella typhi in the first four cases. In case 1 the organism was resistant to chloramphenicol. In case 5 a culture was not drawn but a Widal test showed a characteristic rising titre, from $S$ typhi $O$ negative and $\mathrm{H} 1 / 50$ to $\mathrm{O} 1 / 50$ and $\mathrm{H} 1 / 250$. Liver function tests showed hepatocellular jaundice in four cases and a cholestatic picture in one (table). All patients were negative for hepatitis B surface antigen, and no biliary stones were seen on a plain abdominal $x$ ray film. Oral cholecystography was performed after the jaundice had subsided in cases 1 and 5 and did not show any stones. Percutaneous liver biopsy in cases 2,3 , and 4 showed fatty infiltration of hepatocytes with lymphocytic infiltration of portal triads. In cases 2 and 3 granulomas were seen, but in case 4 no definite granulomas could be made out.

Patients were treated with either co-trimoxazole or chloramphenicol in standard doses. In case 1 the organisms were resistant and required treatment with gentamicin and ampicillin. Corticosteroids were not used. The fever took an average of $15 \cdot 2$ days to respond to treatment. The jaundice subsided with the fever.

One patient (case 1) developed overt hepatic failure with bleeding diathesis; another (case 2 ) had an asymptomatic prolongation of prothrombin time; and a third (case 5) suffered an anicteric relapse three weeks after discharge, which responded to amoxycillin. There were no deaths.

\section{Comment}

Jaundice due to a hepatitis like syndrome in typhoid fever is uncommon. "Hepatitis typhosa" was reported in six out of 530 patients from Iran, ${ }^{1} 0.4 \%$ of 3476 patients from Chile, ${ }^{2}$ and five out of 92 cases from Sri Lanka. ${ }^{3}$ The present study was not a systematic study of typhoid fever, and an exact incidence cannot be given. During this period, however, 925 patients were treated in this hospital with a diagnosis of typhoid fever.

As a group these patients were young and severely ill and had a prolonged and persistent fever even after starting specific chemotherapy. Blood cultures were positive in all patients in whom they were done, and in one case the organism grown was resistant to chloramphenicol. This was also reported by Rowland. ${ }^{1}$ It is noteworthy that none of the patients had received specific treatment before admission, which is distinctly unusual in India. This may explain the severity of their disease.

The pathogenesis of typhoid hepatitis is unclear. Although typhoid endotoxin was once considered to be the cause of many of the manifestations of typhoid fever, more recent evidence indicates that systemic endotoxaemia is unlikely to have any major role. ${ }^{4}$ At the site of multiplication of $S$ typhi, however, as in the liver, high concentrations of endotoxin may provoke a granulomatous or mononuclear inflammatory response. Tolerance to this local reaction does not occur as it does for systemic reactions to endotoxin. ${ }^{5}$ It should be remembered, however, that the liver disease described in typhoid fever may occur in other ulcerative diseases of the intestine-for example, Crohn's disease, amoebiasis, and ulcerative colitis. ${ }^{3}$ In conclusion, typhoid must be kept in mind as an unusual cause of a hepatitis syndrome, especially in endemic areas.

' Rowland MAK. The complications of typhoid fever. $f$ Trop Med Hyg $1961 ; 64$ :

Faierman D, Ross FA, Seckler SG. Typhoid fever complicated by hepatitis, Faierman D, Ross FA, Seckler SG. Typhoid fever co
nephritis and thrombocytopenia. $\mathcal{F} A M A 1972 ; 221: 60-1$

- Ramachandran S, Godfrey JJ, Perera MVF. Typhoid hepatitis. f AMA 1974 ;230 236-40.

4 Butler T, Bell WR, Levin J, Link NN, Arnold K. Typhoid fever-studies of blood coagulation, bacteremia and endotoxemia. Arch Intern Med 1978;138: 407-10.

${ }^{6}$ Hornick RB, Greisman S. On the pathogenesis of typhoid fever. Arch Intern Med 1978;138:357-9.

(Accepted 10 May 1984)

Department of Medicine, St Martha's Hospital, Bangalore 560009 , South India

P PAIS, MD, physician

\section{Inadvertent self administration of superglue: a consumer hazard}

Tissue bonding is a hazard of using cyanoacrylate adhesive (superglue) both in industry and the home. Recently, a new hazard, first reported in America, has been defined ${ }^{1}$ : the similarity between the bottles used as containers for certain superglues and those used for therapeutic eye drops has led to people inadvertently instilling the adhesive into their eyes.

\section{Case report}

A 47 year old man presented as an emergency. A short time previously he had placed drops into his left eye from a bottle that he had assumed contained Clearine eye drops (Optrex). He had in fact picked up a bottle of cyanoacrylate (Super Glue, Bostik Ltd). There was immediate pain and blepharospasm with watering; he then found that he could not open his eye and came straight to the hospital.

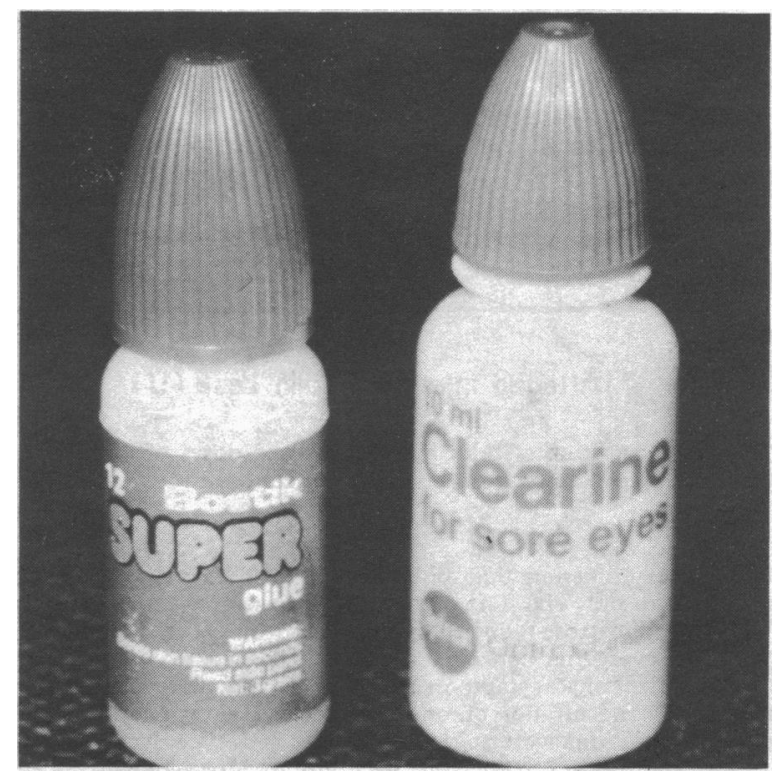

Close similarity between bottles of Super Glue (left) and eye drops (right).

On examination his left lids were totally adherent apart from a small defect medially. Hardened adhesive coated his lid margins and lashes. So that the adhesive would separate from the ocular tissues we filled the conjunctival sac through the small defect with chloramphenicol eye ointment. The eye was then padded, and he was given an analgesic and asked to return the next day. On his return the lashes were carefully cut and the adhesive between his lid margins was divided with scissors. A hardened shell of adhesive could then be gently lifted from the conjunctival sac.

A large underlying corneal and conjunctival epithelial defect healed progressively during the next week, and the eye recovered fully without any further complications. 